\title{
The surface energy balance of Austre Lovénbreen, Svalbard, during the ablation period in 2014
}

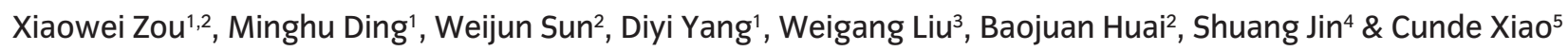 \\ 'State Key Laboratory of Severe Weather, Chinese Academy of Meteorological Sciences, Beijing, China \\ ${ }^{2}$ College of Geography and Environment, Shandong Normal University, Jinan, China \\ ${ }^{3}$ Key Laboratory of Arid Climatic Change and Reducing Disaster of Gansu Province, Key Open Laboratory of Arid Climate Change and Disaster Reduction \\ of China Meteorological Administration, Institute of Arid Meteorology, China Meteorological Administration, Lanzhou, China \\ ${ }^{4}$ State Key Laboratory of Cryospheric Science, Cold and Arid Regions Environmental and Engineering Research Institute, Chinese Academy of \\ Sciences, Lanzhou, China \\ ${ }^{5}$ State Key Laboratory of Earth Surface Processes and Resource Ecology, Beijing Normal University, Beijing, China
}

\section{Abstract}

The ability to simulate the surface energy balance is key to studying land-atmosphere interactions; however, it remains a weakness in Arctic polar sciences. Based on the analysis of meteorological data from 1 June to 30 September 2014 from an automatic weather station on the glacier Austre Lovénbreen, near Ny-Ålesund, Svalbard, we established a surface energy balance model to simulate surface melt. The results reveal that the net shortwave radiation accounts for $87 \%\left(39 \mathrm{~W} \mathrm{~m}^{-2}\right)$ of the energy sources, and is controlled by cloud cover and surface albedo. The sensible heat equals $6 \mathrm{~W} \mathrm{~m}^{-2}$ and is a continuous energy source at the glacier surface. Net longwave radiation and latent heat account for $31 \%$ and $5 \%$ of heat sinks, respectively. The simulated summer mass balance equals $-793 \mathrm{~mm}$ w.e., agreeing well with the observation by an ultrasonic ranger.

\section{Keywords}

High Arctic; Svalbard; snow/ice-air interaction; glacier, radiative fluxes; turbulent fluxes

\section{Correspondence}

Minghu Ding, State Key Laboratory of Severe Weather, Chinese Academy of Meteorological Sciences, No. 46 Zhongguancun South Street, Haidian Ditrict, Beijing 100081, China. E-mail dingminghu@foxmail.com

Abbreviations
AWS: automatic weather station
DOY: day of year
GPS: global positioning system
K: Kelvins
NSE: Nash-Sutcliffe efficiency
PAT: positive accumulated temperature
RMSE: root mean square error
SEB: surface energy balance
SMB: surface mass balance
W $\mathrm{m}^{-2}$ : watt per square metre

\section{Abbreviations}

DOY: day of year

GPS: global positioning system

$K$ : Kelvins RMSE: root mean square error

$\mathrm{W} \mathrm{m}^{-2}$ : watt per square metre

\section{Introduction}

Affected by polar amplification, the Arctic has experienced greater warming than the global average in the past few decades and is also the region where the largest warming is expected in the future (Screen $\delta$ Simmonds 2010; Serreze \& Barry 2011; Aas et al. 2015; IPCC 2019). One of the consequences is the intensification of glacial mass loss (Hanna et al. 2008). Glaciers, as we know, play a vital role in the global ecological environment, water resource security and sea-level rise (Nuth et al. 2010; Radić \& Hock 2014; Conway \& Cullen 2016). The retreat and thinning of this cryospheric element are, therefore, the key scientific issues of climate change.

Mass loss of land-terminating glaciers is mainly driven by an imbalance in snow/ice-air interactions (Arnold et al. 2006), which can be described by the SEB (Kuhn 2011; Karner et al. 2013). The SEB at the glacier-atmosphere interface is controlled by meteorological conditions above the glacier and physical properties (especially the albedo) of the glacier surface (Hock 2005). In the Arctic, glacier melting mainly occurs during summer (Kohler et al. 2002; Oerlemans et al. 201 1; van den Broeke et al. 2011; Bernard et al. 2018).

As a physically based approach, the SEB model is helpful to understand the impacts of climate change on glaciers, reveal the hydrothermal conditions of glacier development and deepen the understanding of surface-atmosphere interaction processes in the cryosphere (Hock 2005; Ding et al. 2020). A large number of SEB experiments have been carried out on the Tibetan Plateau (Zhang et al. 2013; Yang et al. 2016; Sun et al. 2018), Antarctic Ice Sheet (van den Broeke et al. 2004a; Ding et al. 2019) and numerous mountain glaciers in other parts of the world (Wagnon et al. 2003; Mölg \& Hardy 2004; Oerlemans et al. 2009). 
The SEB in the Arctic has also been widely studied (Bougamont et al. 2005; van den Broeke et al. 2011; Ohmura 2012; Franco et al. 2013; Cristóbal et al. 2016). Nakamura and Oort (1988) examined the SEB of the regions poleward of $70^{\circ} \mathrm{N}$ and $70^{\circ} \mathrm{S}$ and provided valuable assessments of their differences. Subsequently, Serreze et al. (2007) studied the impact of net surface flux on the Arctic atmospheric energy balance and found that seasonal cycle changes in atmospheric energy storage were controlled by the net surface flux. More recently, a series of observations and modelling studies have been carried out in Greenland and Alaska (van den Broeke et al. 201 1; Ohmura 2012; Huai et al. 2020).

During the ablation period, net shortwave radiation $\left(S_{\text {net }}\right)$ is the dominant energy source (Nakabayashi et al. 1996; Boike et al. 2003; Westermann et al. 2009); however, it is sensitive to local weather conditions. Raschke \& Ohmura (2005) suggested that spatial albedo variations are large because of the different surface nature (snow cover, permafrost and tundra), which can significantly affect $S_{\text {net }}$. Topography (shading and slope) is also found to play a fundamental role in determining the surface radiation budget (Arnold et al. 2006). Sedlar et al. (2011) showed that the presence of clouds will increase the downward longwave radiation $\left(L_{\mathrm{in}}\right)$ and lead to decreasing incoming shortwave radiation $\left(S_{\text {in }}\right)$. Similarly, Yamanouchi (2018) showed that $L_{\text {in }}$ can be enhanced by moist air intrusion. During polar night, the average $S_{\text {net }}$ is zero, and the sensible heat $(H)$ is the most important and continuous source of energy at the surface (Karner et al. 2013). Snow-ground heat flux $(G)$ has often been neglected in past modelling (Harstveit 1984). However, Boike et al. (2003) suggested that the long duration of the melting period results in a significant loss of heat to the ground.

Svalbard is one of the most glaciated regions in the Arctic, with about $60 \%$ of the total area covered by glaciers (Karner et al. 2013; König et al. 2014). A negative mass-balance trend, in recent decades, has been found and linked to atmospheric warming (Østby et al. 2017; van Pelt et al. 2019). The glaciers in western Svalbard, for example, have been retreating over the last few decades, which has been attributed to the concurrent long-term summer warming (Nordli \& Kohler 2004; König et al. 2014; Nordli et al. 2014).

In recent decades, the decrease in albedo at the glacier and sea-ice surface was found to play an important role in the SEB process because it increases the absorbed solar radiation (Serreze \& Barry 2011; Yang et al. 2011; Zhang et al. 2019). It is known that light-absorbing impurities at the glacier surface can greatly impact the albedo at visible wavelengths (Zhang et al. 2017; Sun et al. 2018). The latest studies by Dou and co-workers (Dou, Du et al. 2019;
Dou, Xiao et al. 2019) found that early rain events can also reduce the surface albedo and bring increased latent heat $(L E)$ to snow/ice. However, there are still a lack of systematic observations and research studies in Svalbard, limiting our understanding of the mechanisms of snow/ ice-air interactions and our ability to couple processes between the atmosphere and the land surface.

The SEB study reported here examined Austre Lovénbreen, a typical polythermal valley glacier in the Arctic, and aimed at improving our understanding of snow/iceair interaction and glacier mass balance in the context of climate change. Meteorological observations were carried out as part of the programme of a Chinese National Arctic Research Expedition during the ablation period in 2014 Based on the data, the components of SEB and its characteristics were assessed.

\section{Study region}

Austre Lovénbreen is a glacier in the vicinity of $\mathrm{Ny}-$ Ålesund in north-western Svalbard (Fig. 1, 78 $52^{\prime} \mathrm{N}$, $\left.12^{\circ} 10^{\prime} \mathrm{E}\right)$. This area is one of the most rapidly warming regions in the Arctic, warming up by $0.76 \pm 0.29^{\circ} \mathrm{C}$ per decade from 1975 to 2014 (Ding et al. 2018), and is strongly influenced by the North Atlantic Current, which leads to a typical maritime climate. The annual precipitation is approximately $400 \mathrm{~mm}$ in Ny-Ålesund, with a steadily rising trend over the last two decades (Bernard et al. 2018). At this high latitude, the polar day lasts from 19 April to 24 August, and the polar night period is from 23 October to 19 February (Deng et al. 2006). The total glacier extent of Svalbard sums up to approximately $33750 \mathrm{~km}^{2}$ (Köhler et al. 2015), with a large number of small valley glaciers $\left(<1 \mathrm{~km}^{2}\right)$ as well as large areas of contiguous ice fields and ice caps (König et al. 2014). Most glaciers are polythermal (Wang et al. 2019) and are very sensitive to climate change. The retreat of Svalbard glaciers over the past 40 years has contributed approximately $0.026 \mathrm{~mm} \mathrm{a}^{-1}$ to sea-level rise (Nuth et al. 2010).

Austre Lovénbreen is relatively small $\left(4.48 \mathrm{~km}^{2}\right)$, with a maximum elevation of no more than $550 \mathrm{~m}$ a.s.l. (Ai et al. 2019). It flows generally northward from the interior of the southern side of the fjord Kongsfjorden onto the coastal plain (König et al. 2014). The average thickness of the Austre Lovénbreen is $76 \mathrm{~m}$, with a maximum thickness of $164 \mathrm{~m}$ (Saintenoy et al. 2011). GPS tracking measurements reveal that the glacier's terminus has been in a state of retreat since 2005 and there are also indications that the glacier has been in retreat since 1948 (Marlin et al. 2017). The retreat rate during 1995-2009 was $5.36 \mathrm{~m} \mathrm{a}^{-1}$ (Midgley et al. 2013), and the average flow velocity during 2005-2018 was $4 \mathrm{~m} \mathrm{a}^{-1}$ 


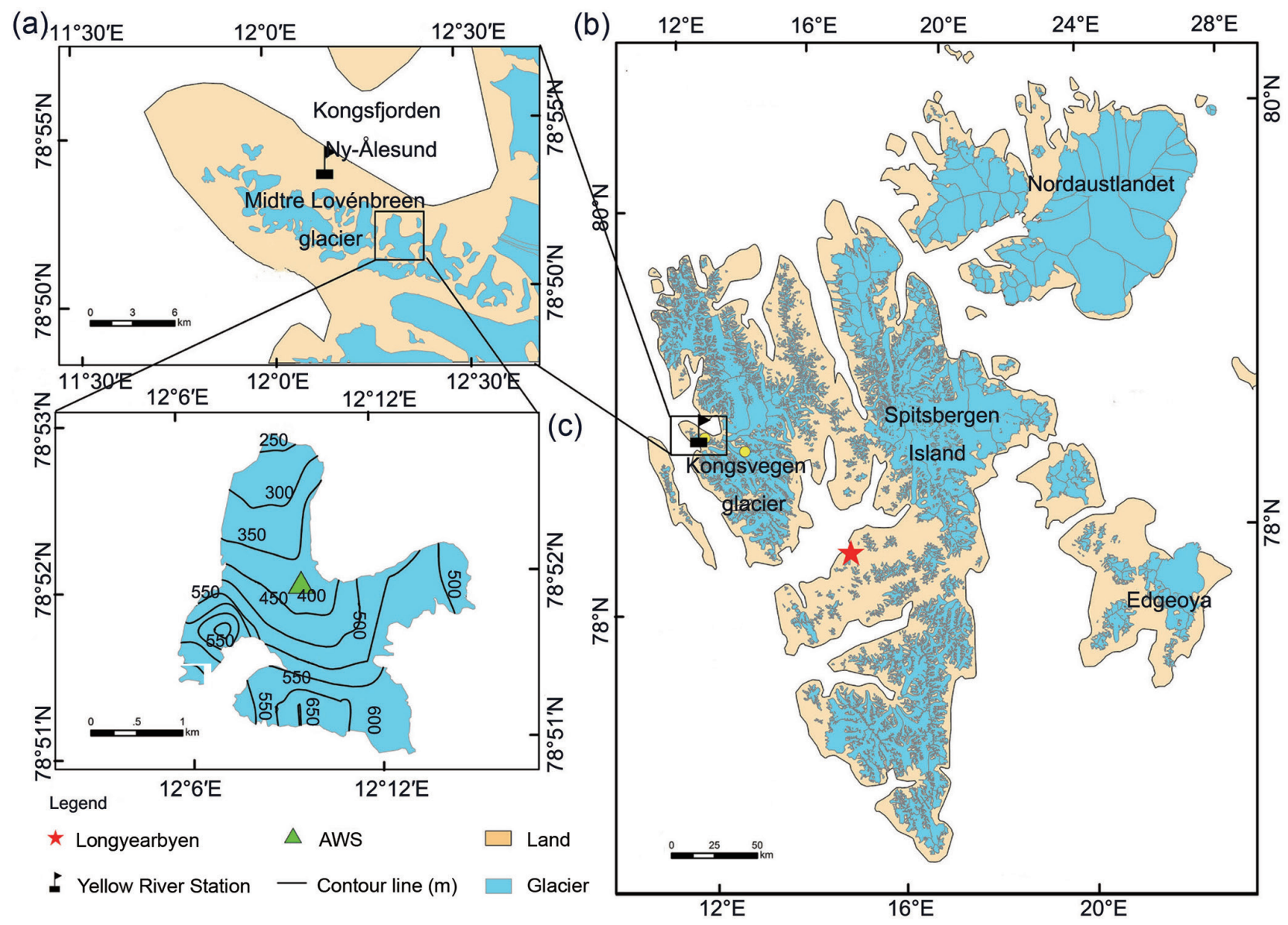

Fig. 1 (a) Location map of Austre Lovénbreen in (b) the archipelago of Svalbard. (c) The extent and contour line distribution of Austre Lovénbreen. The glacier information in the image is from the Randolph Glacier Inventory, downloaded from the World Glacier Monitoring Service.

(Ai et al. 2019). The rate of surface elevation change ranged from +9.6 to about $-106.1 \mathrm{~cm} \mathrm{a}^{-1}$ in the period 2005-2010 (Ai et al. 2012).

\section{Data and processing}

\section{Data sources}

In order to monitor the meteorology of Austre Lovénbreen, an AWS was placed on a relatively flat surface at $337 \mathrm{~m}$ a.s.l. (Fig. 1). Measurements were taken every $10 \mathrm{~s}$, and half-hourly mean values were stored with a CR1000 data logger (Campbell Scientific). Meteorological sensors (Table 1) were installed in strict accordance with the surveying specifications for surface weather. We chose 1 June to 30 September (DOY 152-273) 2014 as the study period. Melt energy and daily melt data from Austre Lovénbreen indicate that the ablation period in 2014 was approximately from 4 June to 16 September.

\section{Data processing}

For all meteorological data in this study, monthly average values were calculated from daily average values, which were retrieved using the half-hourly mean values. Missing values were handled depending on their duration: if more than 50\% (30 minutes) of data were missing within 1 hour, $21 \%$ (ca. 5 hours) of hourly data were missing during one day, or $12 \%$ (ca. 4 days) of daily data were missing within one month, the hourlydaily-monthly data were considered as missing (same method as that of Maturilli et al. 2012). During the observation period, there were gaps in the wind speed data (11/353 day, 3\%), for example, 30 May (DOY 121), 9 June (DOY 160), 13-14 September (DOY 256-257) and 7-9 October (DOY 280-281), and all air-pressure data are missing because of sensor damage. The missing values were supplemented by linear interpolation (air temperature and wind speed) and barometric height formula (air pressure), respectively. The outliers were 
Table 1 AWS sensor specifications.

\begin{tabular}{|c|c|c|c|}
\hline Elements & Sensor type & Range & Accuracy \\
\hline Air temperature & HMP155A & $-80-60^{\circ} \mathrm{C}$ & $\pm\left(0.226-0.0028^{*} T_{\mathrm{a}}\right){ }^{\circ} \mathrm{C}$ at -80 to $20^{\circ} \mathrm{C}$ \\
\hline Relative humidity & HMP155A & $0-100 \%$ & $\pm\left(1.0+0.008 * R H^{\mathrm{a}}\right) \%$ at -20 to $40^{\circ} \mathrm{C}$ \\
\hline Air pressure & CS106 & $500-1100 \mathrm{hPa}$ & $0.3 \mathrm{hPa}$ \\
\hline Wind speed & Young 05103 & $0-100 \mathrm{~m} \mathrm{~s}^{-1}$ & $\pm 0.3 \mathrm{~m} \mathrm{~s}^{-1}$ \\
\hline Wind direction & Young 05103 & $0-360^{\circ}$ & $\pm 3^{\circ}$ \\
\hline $\mathrm{LW}^{c}$ radiation & CNR4 & $300-2800 \mathrm{~nm}$ & 4-10 $\mu \mathrm{V} / \mathrm{W} \mathrm{m}^{2}$ \\
\hline Snow depth & SR50A & $0.5-10 \mathrm{~m}$ & $\pm 1 \mathrm{~cm}$ \\
\hline
\end{tabular}

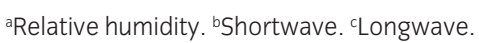

judged by measurement ranges specified by the manufacturers of the sensors (Table 1). They were eliminated if values were outside the measurement range (Sun et al. 2018). Our temperature radiation shields were ventilated, so that the error resulting from radiative heating of temperature probes during periods with low wind speed is very small. As the barometer was broken during observation, the air pressure of Austre Lovénbreen was obtained using the barometric height formula (see below), on the basis of observations from the Arctic Yellow River Station, in Ny-Ålesund (Fig. 1).

Van den Broeke et al. (2004b) reported that snow cover and riming on top of radiation sensors and a low sun angle affect the measurement of solar radiation. When this happens, it generally leads to under- or overestimation of $S_{\text {in }}$. When snow occurs, $S_{\text {in }}$ is calculated from the measured reflected shortwave radiation $\left(S_{\text {ref }}\right)$ divided by the corrected surface albedo, which is 0.9 for fresh snow (Oerlemans \& Klok 2002). The albedo is calculated directly from the $S_{\text {ref }}$ divided by the $S_{\text {in }}$. Similar to Oerlemans and Klok (2002), we corrected the albedo to 0.9 when it exceeded 0.9 during the day. When the sun angle was less than $0^{\circ}, S_{\text {ref }}$ and $S_{\text {in }}$ were corrected to 0 . The installation height of the sensor may have caused additional radiation to reach the sensor, resulting in an overestimation of upward longwave radiation $\left(L_{\text {out }}\right)$, which may exceed $315 \mathrm{~W} \mathrm{~m}^{-2}$; according to the StefanBoltzmann law, $L_{\text {out }}$ can never exceed $315 \mathrm{~W} \mathrm{~m}^{-2}$ during the glacier melt period (Oerlemans et al. 2009). In this study, such high values were excluded if they occurred.

\section{Methods}

\section{Estimating air pressure and cloud cover}

In this study, the air-pressure data for Austre Lovénbreen were calculated by the barometric height formula and pressure data from the Arctic Yellow River Station
(Wei et al. 2016). Taking the Arctic Yellow River Station as the base level, the atmosphere is approximately regarded as isothermal:

$$
\begin{aligned}
& H_{\mathrm{y}}=H_{\mathrm{a}}+R_{\mathrm{d}} / g\left(273.15+T_{\mathrm{a}} \ln \left(P_{\mathrm{y}} / P_{\mathrm{a}}\right)\right. \\
& H_{\mathrm{y}}-H_{\mathrm{a}}=18400\left(1+T_{\mathrm{a}} / 273.15\right) \log \left(P_{\mathrm{y}} / P_{\mathrm{a}}\right),
\end{aligned}
$$

where $H_{y}$ and $H_{a}$ are the elevations of the Arctic Yellow River Station and Austre Lovénbreen, respectively. $R_{\mathrm{d}}$ is the specific gas constant of dry air $\left(287.05 \mathrm{~J} \mathrm{~kg}^{-1} \mathrm{~K}^{-1}\right) . T_{\mathrm{a}}$ is the air temperature $(\mathrm{K}) . P_{\mathrm{y}}$ and $P_{\mathrm{a}}$ are the air pressures at the Arctic Yellow River Station and Austre Lovénbreen, respectively.

There are many parameterisation schemes to calculate clouds, using shortwave radiation (Favier et al. 2004), longwave radiation (van den Broeke et al. 2006) or relative humidity (Liston \& Elder 2006). Van den Broeke et al. (2006) suggested that longwave radiation was suitable for the calculation of clouds in polar regions and more transferable (Chen et al. 2018). The method (Chen et al. 2018) can be expressed as follows:

$$
\begin{aligned}
& L_{\mathrm{in}}=\varepsilon_{\mathrm{eff}} \sigma T_{\mathrm{a}}^{4} \\
& \varepsilon_{\mathrm{eff}}=\varepsilon_{\mathrm{ad}}+0.443\left(e_{\mathrm{a}} / T_{\mathrm{a}}\right)^{0.125} \\
& n_{\mathrm{c}}=\left(\varepsilon_{\mathrm{eff}}-\varepsilon_{\mathrm{cs}}\right) /\left(\varepsilon_{\mathrm{ov}}-\varepsilon_{\mathrm{cs}}\right) \\
& n_{\mathrm{c}}\left(n_{\mathrm{c}}>1\right)=1 ; n_{\mathrm{c}}\left(n_{\mathrm{c}}<0\right)=0,
\end{aligned}
$$

where $n_{\mathrm{c}}$ is the cloud fraction, $e_{\mathrm{a}}$ is water vapour pressure (hPa), $\varepsilon_{\text {eff }}$ is the actual effective emissivity, and $\varepsilon_{\text {ad }}$ and $\varepsilon_{\text {ov }}$ are the emissivity for a dry atmosphere (0.22) (Dürr \& Philipona 2004) and overcast condition, respectively.

\section{Estimating the SEB}

According to Oke (1987), the glacier volume, rather than a thin layer at the glacier surface, was defined as 
the object of this study. This volume extends from the glacier surface to a depth, where the vertical heat flux is nonsignificant. The full SEB expression of Oke (1987), which ignored horizontal heat fluxes, is expressed as follows (all fluxes are in $\mathrm{W} \mathrm{m}^{-2}$ and towards the surface are defined positive):

$$
Q_{\mathrm{m}}=R_{\mathrm{n}}+H+L E+Q_{\mathrm{p}}+G,
$$

where $Q_{\mathrm{m}}$ is the melt energy; when the surface temperature is less than $0{ }^{\circ} \mathrm{C}, Q_{\mathrm{m}}=0$, whereas when it reaches $0{ }^{\circ} \mathrm{C}$, that is, the melting point (van den Broeke et al. 2004a), melting happens and the melt energy $Q_{\mathrm{m}}$ is derived from Eqn. 3. $R_{\mathrm{n}}$ is the net radiation and can be expressed as $R_{\mathrm{n}}=S_{\text {ref }}+S_{\text {in }}+L_{\text {out }}+L_{\text {in }} ; H$ and $L E$ are turbulent fluxes of sensible and latent heat, respectively. $G=K_{t} \partial t /$ $\partial z$ is the surface value of the subsurface (conductive) heat flux, which can be estimated using the effective thermal conductivity $K_{t}: 0.4 \mathrm{~W} \mathrm{~m}^{-1} \mathrm{~K}^{-1}$ for old snow and $2.2 \mathrm{~W} \mathrm{~m}^{-1} \mathrm{~K}^{-1}$ for pure ice (Oke 1987). Sun et al. (2016) observed that there was nearly no temperature variability at the depth of $-20 \mathrm{~m}$, which meets the requirement of the non-significant vertical heat transfer as suggested by Oke (1987). We therefore selected the $-20 \mathrm{~m}$ temperature to derive $G$. However, the resulting $G$ values calculated according this approach did not properly capture the seasonal pattern of subsurface heat exchange and may have underestimated heat transport during the melt season between the surface and the subsurface. In addition, the radiation penetration was ignored as it has little influence on $Q_{\mathrm{m}}$ in the Arctic (van den Broeke, Smeets, Ettema, van der Veen et al. 2008). $Q_{\mathrm{p}}$ is the heat supplied by rain and was also neglected, as it is non-significant and negligible compared with the other components in the equation (Karner et al. 2013). A study conducted on Kongsvegen (Karner et al. 2013), which is in the vicinity of Austre Lovénbreen, illustrated that $Q_{p}$ contributed less than $1 \%$, on average, to the $Q_{\mathrm{m}}$. The SEB was calculated at half-hour intervals.

Turbulent fluxes were calculated using the bulk-aerodynamic method (van den Broeke et al. 2005). $H$ and $L E$ are expressed as follows:

$$
\begin{aligned}
& H=\rho_{\mathrm{o}} c_{\mathrm{p}} u_{*} \theta_{*}=\rho_{\mathrm{o}} c_{\mathrm{p}} C_{H} u\left(T_{\mathrm{a}}-T_{\mathrm{s}}\right) \\
& L E=\rho_{\mathrm{o}} L_{\mathrm{v}} u_{*} q_{*}=\rho_{\mathrm{o}} L_{\mathrm{v}} C_{E} u\left(q-q_{\mathrm{s}}\right),
\end{aligned}
$$

where $c_{\mathrm{p}}\left(1005.7 \mathrm{~J} \mathrm{~kg}^{-1} \mathrm{~K}^{-1}\right)$ is the specific heat capacity of air and $\rho_{\mathrm{o}}\left(1.29 \mathrm{~kg} \mathrm{~m}^{-3}\right)$ is the air density at standard atmospheric pressure $P_{\mathrm{o}}(1013.25 \mathrm{hPa}) . u_{*} \theta_{*}$ and $q_{*}$ are the turbulent scales of vertical velocity, potential temperature and specific humidity, respectively. $T_{\mathrm{a}}$ and $u$ are the air temperature $(\mathrm{K})$ and wind speed $\left(\mathrm{m} \mathrm{s}^{-1}\right)$ at height $z$, respectively; $T_{\mathrm{s}}$ and $q_{\mathrm{s}}$ are the glacier surface temperature
(K) and the surface saturated specific humidity $\left(\mathrm{g} \mathrm{kg}^{-1}\right)$, respectively; $T_{\mathrm{s}}$ is calculated using the Stephan-Boltzmann formula combined with $L_{\text {out }}$ and $q_{\mathrm{s}}=0.622 e_{\mathrm{s}} / P$, where $e_{\mathrm{s}}$ and $P$ are the glacier surface saturation vapour pressure and the air pressure, respectively. $L_{v}$ is the latent heat of evaporation (2.501 $\mathrm{MJ} \mathrm{kg}^{-1} \mathrm{k}^{-1}$ ) or sublimation (2.834 $\mathrm{MJ} \mathrm{kg} \mathrm{kg}^{-1}$ ). $C_{H}$ and $C_{E}$ are the heat and water vapour transport coefficients, respectively.

There are many parameterisation schemes to calculate $C_{H}$ and $C_{E^{\prime}}$ including those of Businger et al. (1971), Louis et al. (1982) and Beljaars \& Holtslag (1991). Ma et al. (2011) compared the applicability of these schemes with the Antarctic ice-air interaction process, finding that the scheme of Louis et al. (1982) performed best in polar areas. This scheme was also historically implemented to prevent surface-atmosphere decoupling over land in three-dimensional simulations. Therefore, we applied the Louis function, according to which the Richardson number $R_{\mathrm{ib}}$ is used as the stability factor to parameterise $C_{H}$ and $C_{E}$ :

$$
\begin{aligned}
& u_{*} \theta_{*}=a^{2} / \operatorname{Pru} \Delta \theta F_{\mathrm{h}}\left(z / z_{\mathrm{om}}, R_{\mathrm{ib}}\right) \equiv C_{H} u \Delta \theta \\
& u_{*} q_{*}=a^{2} / \operatorname{Pru} \Delta q F_{\mathrm{h}}\left(z / z_{\mathrm{om}}, R_{\mathrm{ib}}\right) \equiv C_{E} u \Delta q
\end{aligned}
$$

For unstable conditions:

$$
F_{\mathrm{h}}\left(z / z_{\mathrm{om}}, R_{\mathrm{ib}}\right)=1-3 b R_{\mathrm{ib}} /\left(1+3 b c_{h} a^{2}\left|R_{\mathrm{ib}}\left(1+z / z_{\mathrm{om}}\right)\right|^{1 / 2}\right) .
$$

For stable conditions:

$$
F_{\mathrm{h}}\left(z / z_{\mathrm{om}}, R_{\mathrm{ib}}\right)=1-1 /\left(1+3 b R_{\mathrm{ib}}\left(1+d R_{\mathrm{ib}}\right)^{1 / 2}\right),
$$

where $z$ and $z_{\text {om }}$ are the height of observation and the surface roughness length, respectively. When the glacier surface is covered with snow, a constant $z_{\text {om }}(0.46 \mathrm{~mm})$ can be used, which is determined from the calculation of the wind velocity profile law under 'near-neutral' conditions (van den Broeke et al. 2005). The $z_{\text {om }}$ values of Austre Lovénbreen were consistent with those for the nearby Midtre Lovénbreen glacier: ice: $0.66 \mathrm{~mm}$ and snow: $0.22 \mathrm{~mm}$ (Arnold \& Rees 2003; Arnold et al. 2006). $a^{2}=k^{2} /\left[\ln \left(z / z_{\mathrm{om}}\right)\right]^{2}$, where $b=5, c_{h}=5$ and $d=5$. $P_{\mathrm{r}}$ is the ratio of momentum and drag coefficient under neutral conditions, which are 1 and 0.5 for stable and unstable conditions, respectively. When $R_{\mathrm{ib}}$ is positive, the surface layer is stable, and when $R_{\mathrm{ib}}$ is negative, the surface layer is unstable. In this study, we choose the Louis function because it also allowed us to obtain a simple analytical solution. However, the longtail functions produced too much mixing compared with local observations (Chechin et al. 2019).

Glacier SMB is the sum of accumulation and ablation. On Austre Lovénbreen, SMB was obtained by monitoring 
the change of surface elevation with a sonic ranger and using standard density values for snow and ice: a density of $890 \mathrm{~kg} \mathrm{~m}^{-3}$ for ice and the density of $200 \mathrm{~kg} \mathrm{~m}^{-3}$ for fresh snow (snowfall), and $380 \mathrm{~kg} \mathrm{~m}^{-3}$ for old snow. The main formula of the simulated SMB (in $\mathrm{m}$ w.e.) is given by the following equation (Klok \& Oerlemans 2002; Jiang et al. 2010):

$$
\mathrm{SMB}=\int\left(M+M_{E}+P_{\text {snow }}\right) d t,
$$

where $M$ is the melt rate ( $\mathrm{m}$ w.e. $\mathrm{s}^{-1}$ ) and $M_{E}$ is the sublimation-deposition-condensation rate $\left(\mathrm{m}\right.$ w.e. $\left.\mathrm{s}^{-1}\right)$. At half-hourly intervals, the melt rate follows from $M=Q_{\mathrm{m}}$ ' $\left(L_{\mathrm{f}} r_{\mathrm{w}}\right)$, where $L_{\mathrm{f}}=0.344 \mathrm{MJ} \mathrm{kg}^{-1} \mathrm{~K}^{-1}$ is the latent heat of fusion and $r_{\mathrm{w}}=1000 \mathrm{~kg} \mathrm{~m}^{-3}$ is the water density. The surface sublimation-deposition-condensation rate is derived from the $L E$ using $M_{E}=L E /\left(L_{\mathrm{v}} r_{\mathrm{w}}\right)$, where $L_{\mathrm{v}}$ is the latent heat of condensation $\left(2.501 \mathrm{MJ} \mathrm{kg}^{-1} \mathrm{~K}^{-1}\right)$ with a surface temperature of $0{ }^{\circ} \mathrm{C}$ ) or sublimation/deposition (2.834 $\mathrm{MJ} \mathrm{kg}{ }^{-1} \mathrm{~K}^{-1}$ ) with a surface temperature below $\left.0{ }^{\circ} \mathrm{C}\right)$. The sum of sublimation/deposition/condensation and melting is the ablation of the glacier. $P_{\text {snow }}$ is the snowfall $(\mathrm{m})$. For rainfall, we assumed that it directly produces runoff, and the refreezing of melt and rain water in the snowpack was not taken into account. Snowfall represented the accumulation part of glacier SMB. Following van Pelt and Kohler (2015), the threshold temperature for distinguishing rainfall and snowfall in Svalbard was set to 1.5 ${ }^{\circ} \mathrm{C}$. We found that the total precipitation was dominated by snowfall ( $65 \%$ of total).

In order to evaluate the reliability of the SEB model, we use measured and simulated cumulative mass-balance values in combination with the RMSE and the NSE to evaluate the model. The RMSE is calculated as follows:

$$
\mathrm{RMSE}=\sqrt{\frac{1}{n} * \sum_{t=1}^{n}\left(y_{t}-y_{t}^{*}\right)^{2}}
$$

where $n$ is the observation time, and $y_{t}$ and $y_{t}^{*}$ are the measured and simulated accumulated mass-balance values, respectively.

The NSE is generally used in the verification or evaluation of hydrological models (Nash \& Sutcliffe 1970):

$$
\mathrm{NSE}=1-\frac{\sum_{t=1}^{n}\left(y_{t}-y_{t}^{*}\right)^{2}}{\sum_{t=1}^{n}\left(y_{t}-\overline{y_{t}^{*}}\right)^{2}},
$$

where $t$ is the observation time, $n$ is the number of samples, and $y_{t}$ and $y_{t}^{*}$ are the measured and simulated accumulated mass-balance values, respectively. $\bar{y}_{t}^{*}$ is the mean of $y_{t}^{*}$.

\section{Results and discussion}

\section{Meteorological conditions}

General weather conditions in the Austre Lovénbreen environment can be described by meteorological data from the AWS. Figure 2 shows the variability of meteorological variables for the daily averages on Austre Lovénbreen from 30 April 2014 to 17 April 2015. The average air temperature of Austre Lovénbreen $\left(T_{\mathrm{a}}\right)$ was $-5.5{ }^{\circ} \mathrm{C}$. The mean daily $T_{\text {a }}$ ranged from $-25.1{ }^{\circ} \mathrm{C}$ (1 1 February, DOY 42 ) to $7.3^{\circ} \mathrm{C}$ (24 July, DOY 205), and the variation was obvious, especially in the non-ablation period. The area is often affected by moist air intrusions (Yamanouchi 2018). These warm states coincide with periods (grey shading in Fig. 2) of high $T_{a^{\prime}}$ high relative humidity and specific humidity $(q)$, for example, 24-27 October (DOY 297-300), 4-10 January (DOY 4-10), 16-18 February (DOY 47-49) and 4-9 March (DOY 63 to 68). The daily average $T_{a}\left(0.9^{\circ} \mathrm{C}\right)$ remained above the melting point of ice $\left(0^{\circ} \mathrm{C}\right)$ during the ablation period. It had a daily average of $2.3 \mathrm{~g} \mathrm{~kg}^{-1}$ and a peak of $3.5 \mathrm{~g} \mathrm{~kg}^{-1}$. During the ablation period, accompanied by the strong melting point, $T$ and $q$ showed high values.

The average air pressure $(P)$ was $964 \mathrm{hPa}$. The daily mean wind speeds typically ranged from 0 to $8.2 \mathrm{~m} \mathrm{~s}^{-1}$ but seldom exceeded $8 \mathrm{~m} \mathrm{~s}^{-1}$, with a median of $2 \mathrm{~m} \mathrm{~s}^{-1}$ during the ablation period (Fig. 2d), which is much lower than wind speeds observed on the adjacent Kongsvegen glacier (5.7 $\mathrm{m} \mathrm{s}^{-1}$; Pramanik et al. 2019). Compared with the whole ablation period $\left(1.7 \mathrm{~m} \mathrm{~s}^{-1}\right)$, the wind speeds in the beginning of the ablation period (4-14 June, DOY 155-165) were relatively low $\left(1.2 \mathrm{~m} \mathrm{~s}^{-1}\right)$. During the non-ablation period, the daily wind speeds were high and variable, with the values frequently exceeding $3 \mathrm{~m} \mathrm{~s}^{-1}$. Figure 3 presents the typical frequency distribution of wind directions observed at the glacier. The prevalent wind direction was south-east (south-south-east + south-east + east-south-east) and occurred $46 \%$ of the time. The wind direction is primarily associated with katabatic forcing and topography. Interestingly, the prevalent wind direction during the ablation period differed in no obvious way from the annual average.

\section{Radiative fluxes}

The daily mean $S_{\mathrm{in}^{\prime}} S_{\mathrm{ref}^{\prime}} L_{\mathrm{in}^{\prime}} L_{\mathrm{out}^{\prime}} R_{\mathrm{n}^{\prime}}$ cloud fraction and albedo from 1 June to 30 September of Austre Lovénbreen are shown in Fig. 4. Austre Lovénbreen experiences polar night from October until February and abundant solar insolation during the polar day period, accounting for $82 \%$ of the insolation for the whole year (Deng et al. 2006). The average cloud cover of Austre 


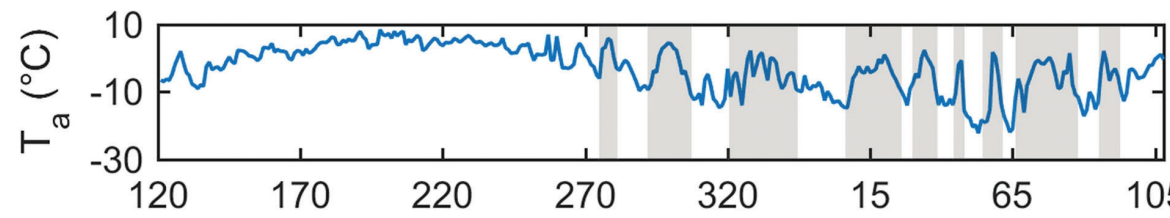

(a)
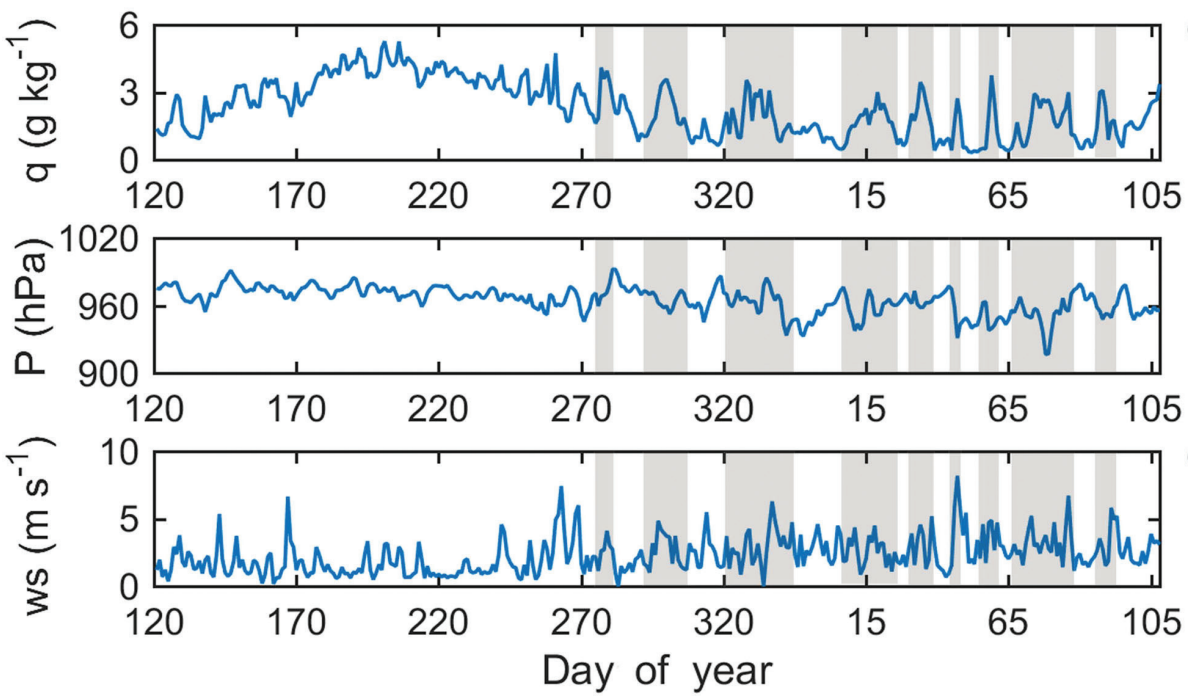

Fig. 2 Daily means of meteorological variables observed at Austre Lovénbreen, Ny-Ålesund, during 30 April 2014-17 April 2015: (a) air temperature ( $\left.T_{a}\right)$, (b) specific humidity (q), (c) air pressure ( $P$ ) and (d) wind speed (ws). Grey shading represents the periods of moist air intrusions.
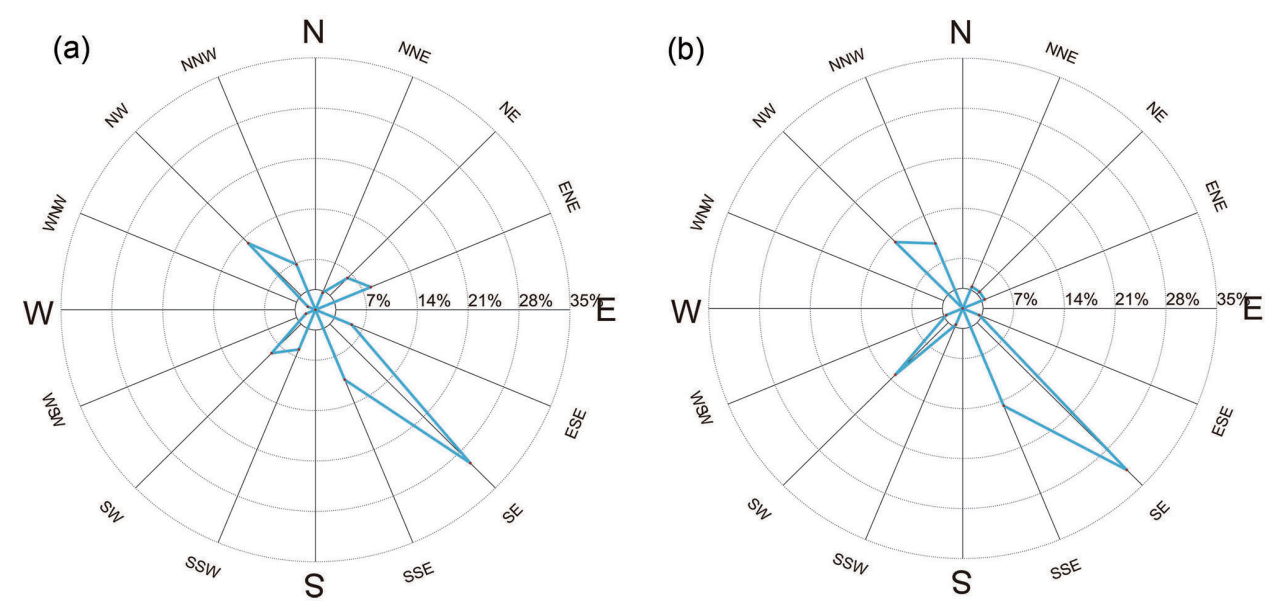

Fig. 3 Wind rose on Austre Lovénbreen during (a) 30 April 2014-17 April 2015 and (b) the ablation period of 1 June-30 September 2014. Katabatic wind from the glacier is the prevalent wind and wind from the Spitsbergen ice cap has less influence during summer.

Lovénbreen was 0.73 during the ablation period, which had a significant impact on radiation (Beesley 2000). The daily means of $S_{\text {in }}$ showed high fluctuations due to variable cloudiness, sun angle and the length of day, varying from $14 \mathrm{~W} \mathrm{~m}^{-2}$ to $396 \mathrm{~W} \mathrm{~m}^{-2}$. Compared with the daily means of $S_{\text {in }}\left(239 \mathrm{~W} \mathrm{~m}^{-2}\right)$ and $S_{\text {ref }}\left(193 \mathrm{~W} \mathrm{~m}^{-2}\right)$ during the melting period in 2011 (from June to August) of Kongsvegen, measured at an altitude of $668 \mathrm{~m}$ a.s.l. (Sauter \& Obleitner 2015), the $S_{\text {in }}\left(159 \mathrm{~W} \mathrm{~m}^{-2}\right)$ and $S_{\text {ref }}$ $\left(118 \mathrm{~W} \mathrm{~m}^{-2}\right)$ of Austre Lovénbreen were small. This difference of $S_{\text {in }}$ can partly be attributed to the cloudiness, which was, on average, 0.73 for Austre Lovénbreen and 0.60 for Kongsvegen (Kupfer et al. 2006; Sauter \& Obleitner 2015). Another vital factor is the altitude: $337 \mathrm{~m}$ a.s.l. 

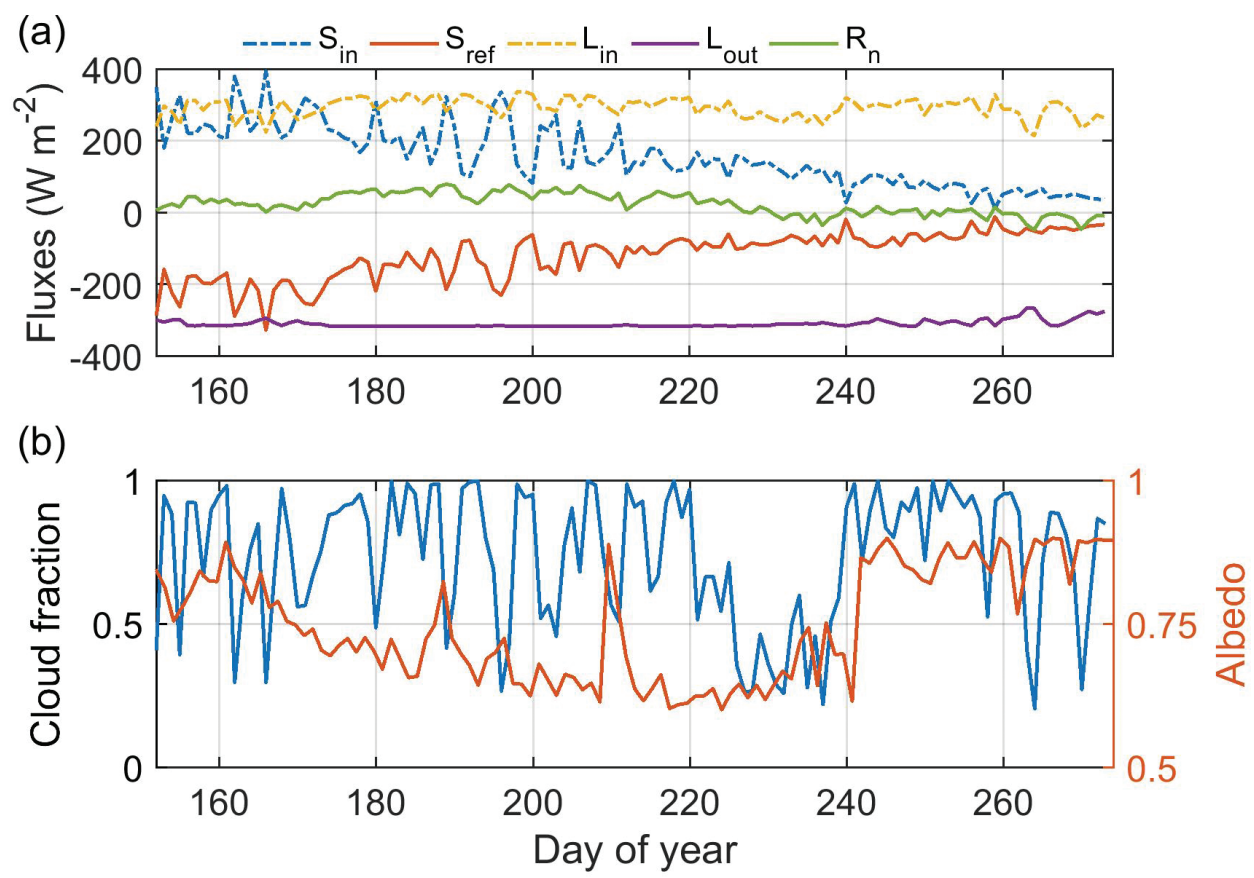

Fig. 4 Daily mean of radiation, cloud and albedo for Austre Lovénbreen, Ny-Ålesund, during 1 June-30 September 2014: (a) incoming $\left(S_{\text {in }}\right) /$ reflected $\left(S_{\text {ref }}\right)$ shortwave radiation, downward $\left(L_{\text {in }}\right) /$ upward $\left(L_{\text {out }}\right)$ longwave radiation and net $\left(R_{n}\right)$ radiation; (b) cloud fraction and albedo.

for Austre Lovénbreen and $668 \mathrm{~m}$ a.s.l. for Kongsvegen (Sauter \& Obleitner 2015). The cloud cover affects $S_{\text {in }}$ by reducing atmospheric transmittance. When the atmospheric transmittance was low under overcast conditions, $S_{\text {in }}$ was small (e.g., 12 July and 2 August, DOY 193 and 214), while $S_{\text {in }}$ was high under clear-sky conditions. $L_{\text {out }}$ is controlled by $T_{\mathrm{s}}$, and $L_{\mathrm{in}}$ is affected by cloud cover, air temperature and relative humidity (Conway $\&$ Cullen 2016). $L_{\text {in }}$ was significantly positively correlated with cloud cover (correlation coefficient $[R]=0.84$, number of samples $[n]=122$, significance level $[p]=0.01)$ and air temperature $(R=0.47, n=122, p=0.01)$. The daily mean values of $L_{\text {in }}$ and $L_{\text {out }}$ were 294 and $312 \mathrm{~W} \mathrm{~m}^{-2}$, respectively. $L_{\text {out }}$ was less variable than $L_{\text {in }}$ on account of relatively minor $T_{\mathrm{s}}$ variations. Rapid weather pattern changes often led to strong short-term variations of relative humidity, $T_{\mathrm{a}}$ and cloud cover, which, in turn, led to highly variable $L_{\mathrm{in}}$, especially before and after 6 July (DOY 187), 10 July (DOY 191), 18 July (DOY 199) and 23 July (DOY 204), and $L_{\text {in }}$ frequently exceeded $L_{\text {out }}$. Therefore, the daily mean values of net longwave radiation $\left(L_{\text {net }}\right)$ were positive during these events and made positive contributions to the SEB.

The average $R_{\mathrm{n}}$ was positive $\left(22 \mathrm{~W} \mathrm{~m}^{-2}\right)$ because of strong $S_{\text {net }}$ input. Figure 4 a shows significant variability in $R_{\mathrm{n}}$ from June to September, ranging from $34 \mathrm{~W} \mathrm{~m}^{-2}$ to $-4 \mathrm{~W} \mathrm{~m}^{-2}$. The albedo of the observation sites on Austre Lovénbreen shows marked variations and the daily mean value was 0.76 , which is of the same order of magnitude as the average albedo (from June to August) of a weather station site on Kongsvegen in 201 1: 0.80 (Sauter $\&$ Obleitner 2015). Figure $4 \mathrm{~b}$ shows that, on average, the lowest monthly values of albedo (0.67) were reported in August, one month after the maximum intensity of $R_{\mathrm{n}}$. Frequent snowfall, especially in September, contributed to maintaining high albedo during the ablation period.

\section{Turbulent fluxes}

Turbulent energy mainly comes from mechanical and buoyancy work (Sheng 2013). H and LE are dependent on a series of factors, including air-surface temperature, specific humidity and wind speed. The daily mean values of $H$ and $L E$ are illustrated in Fig. 5. The average daily value of $H$ was $6 \mathrm{~W} \mathrm{~m}^{-2}$ during the ablation period, with values ranging from -14 to $56 \mathrm{~W} \mathrm{~m}^{-2}$. $H$ was mostly positive on a daily scale, indicating that the surface temperature was less than $T_{a^{\prime}}$ which led to energy transport from the atmosphere to the glacier surface. $H$ is controlled by wind speed and the temperature difference between the atmosphere and surface and, as such, is strongly weather dependent. For example, on 18 July (DOY 199), the average temperature difference between the air and surface was ca. $6{ }^{\circ} \mathrm{C}$, and the average wind speed was $3.1 \mathrm{~m} \mathrm{~s}^{-1}$; meanwhile, $H$ was $34 \mathrm{~W} \mathrm{~m}^{-2}$. Large $H$ values 


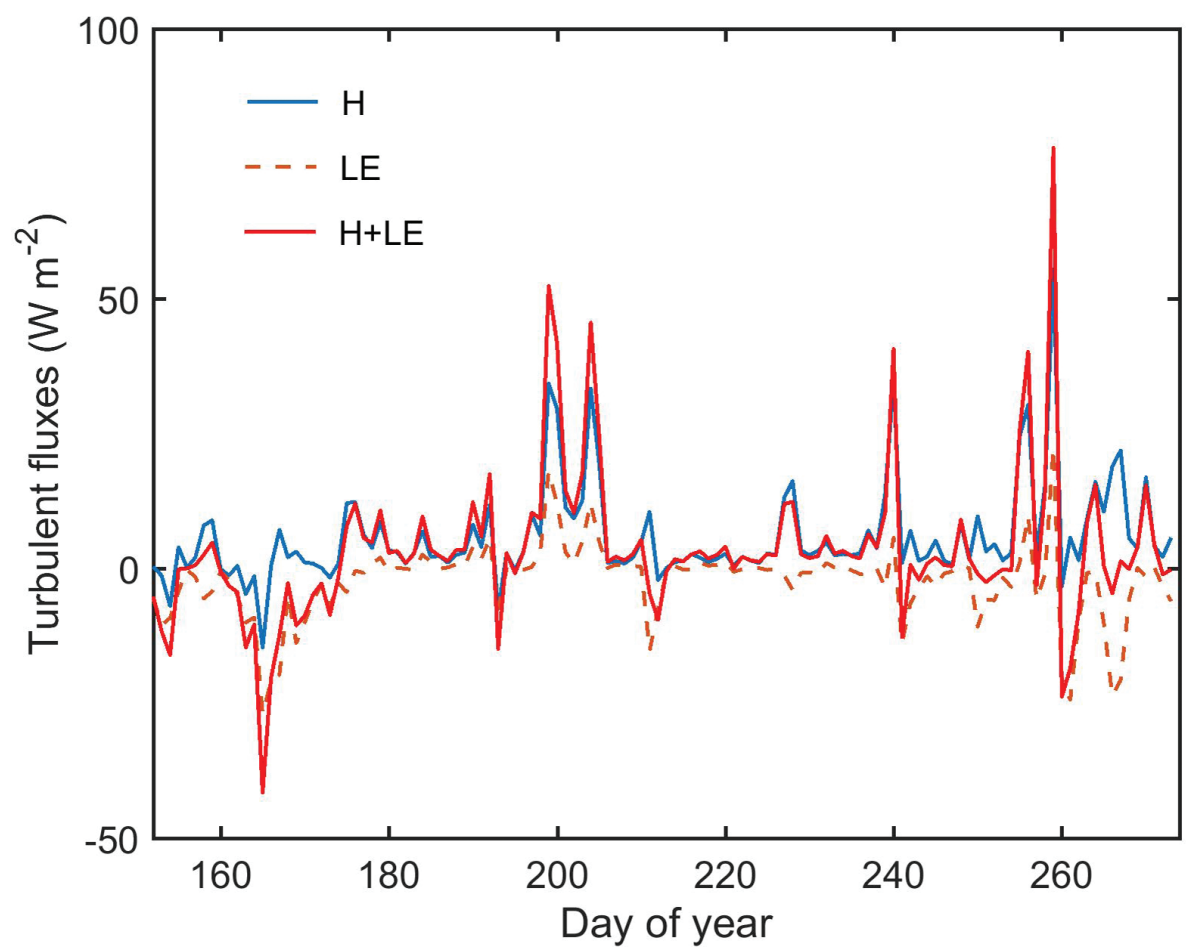

Fig. 5 Daily means of turbulent fluxes for Austre Lovénbreen, Ny-Ålesund, during 1 June-30 September 2014.

(more than $20 \mathrm{~W} \mathrm{~m}^{-2}$ ) were found on 12, 13 and 16 September (DOY 255, 256 and 259), and rapid day-to-day changes occurred. The main reasons include the following: through the analysis of $T_{a^{\prime}} q$ and $p$, the glacier may be influenced by the frequent passage of relatively warm northward-moving low-pressure systems from the ocean, resulting in a large temperature gradient between the surface and the air, coupled with the strong katabatic wind along the glacier; thus, the glacier surface received extensive heat from the atmosphere. The daily $L E$ is mostly negative, with an average of $-2 \mathrm{~W}^{-2}$. This result indicates that mass was lost through sublimation and evaporation. Surface sublimation rather than evaporation dominated the moisture exchanges ( $56 \%$ vs. $44 \%$ ). LE is also susceptible to variable weather; for instance, on 20 July and 16 September (DOY 201 and 259), the glacier may also have been affected by warm advection from the ocean. The increased $T_{\mathrm{a}}$ and humidity, as well as the strong wind, resulted in $q$ exceeding $q_{\mathrm{s}}$ (humidity inversion). Generally, $L E$ was relatively weak in turbulent fluxes $(H+L E$; Fig. 5).

\section{Surface energy budget}

The surface energy budget over the period from 1 June to 30 September 2014 is provided in Fig. 6. The total of these energy fluxes determines whether melting occurs. The monthly average $S_{\text {net }}$ was $39 \mathrm{~W} \mathrm{~m}^{-2}$, higher than $L_{\text {net }}$ $\left(-14 \mathrm{~W} \mathrm{~m}^{-2}\right)$. Stimulated by a low albedo, the monthly $S_{\text {net }}$ reached $61 \mathrm{~W} \mathrm{~m}^{-2}$ in July. Amongst the inputs of surface energy, $S_{\text {net }}$ was the most important contributor, accounting for $87 \%$ of the energy input totals. However, under the influence of low $S_{\text {in }}$ and high albedo, the monthly $S_{\text {net }}$ was only $4 \mathrm{~W} \mathrm{~m}^{-2}$ in September. The monthly average $H$ was $6 \mathrm{~W} \mathrm{~m}^{-2}$ and accounted for $13 \%$ of the total energy input. The magnitude and proportion of $H$ were highest in September. $H$ is the only source of energy during the polar night (Karner et al. 2013; Ding et al. 2019).

During the ablation period, a positive radiation budget and turbulent sensible heat provide energy for glacier melting. The monthly mean $Q_{\mathrm{m}}$ was $-29 \mathrm{~W} \mathrm{~m}^{-2}$, accounting for $63 \%$ of the total energy output. Compared with the other months, $Q_{\mathrm{m}}$ in September was smallest at $-7 \mathrm{~W} \mathrm{~m} \mathrm{~m}^{-2}$. The reason for this difference was the high albedo and low PAT, which refers to the temporal integral of near-surface temperatures $(\mathrm{T})$ exceeding the melting point. The calculated $Q_{\mathrm{m}}$ and the SR 50A recording indicated that ablation mainly occurred in July. Generally, glacier melt was dominated by $S_{\text {net }}(R=0.59, n=122$, $p=0.01)$. There was a significant positive correlation between $Q_{\mathrm{m}}$ and PAT $(R=0.86, n=122, p=0.01)$, as shown in Fig. 7. Variations in albedo also influenced 


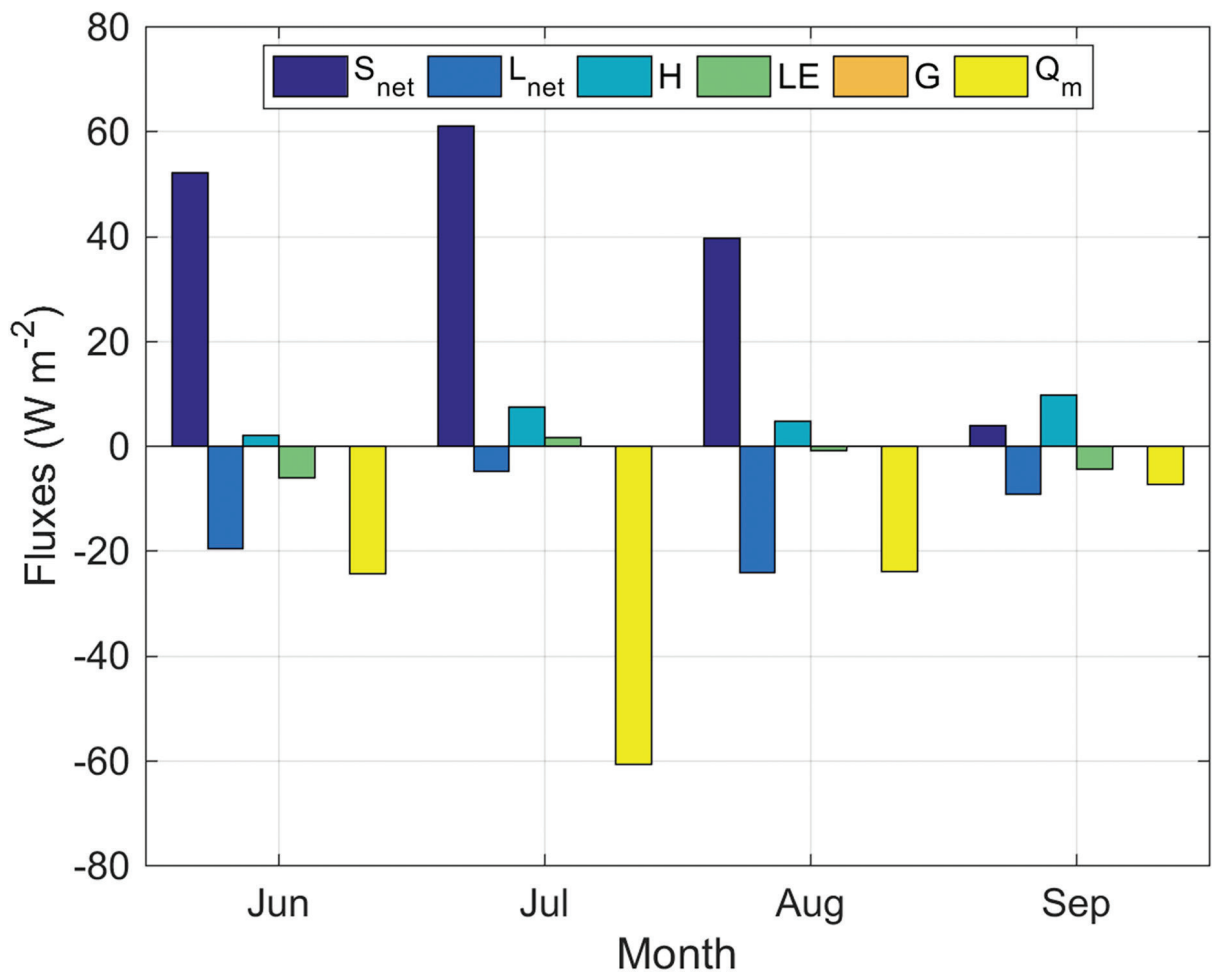

Fig. 6 Surface energy $\left(S_{\text {net }}\right.$ : net shortwave radiation, $L_{n e t}$ : net longwave radiation, $H$ : sensible heat, $L E$ : latent heat, $Q_{m}$ : melt energy) budget of Austre Lovénbreen during 1 June-30 September 2014.
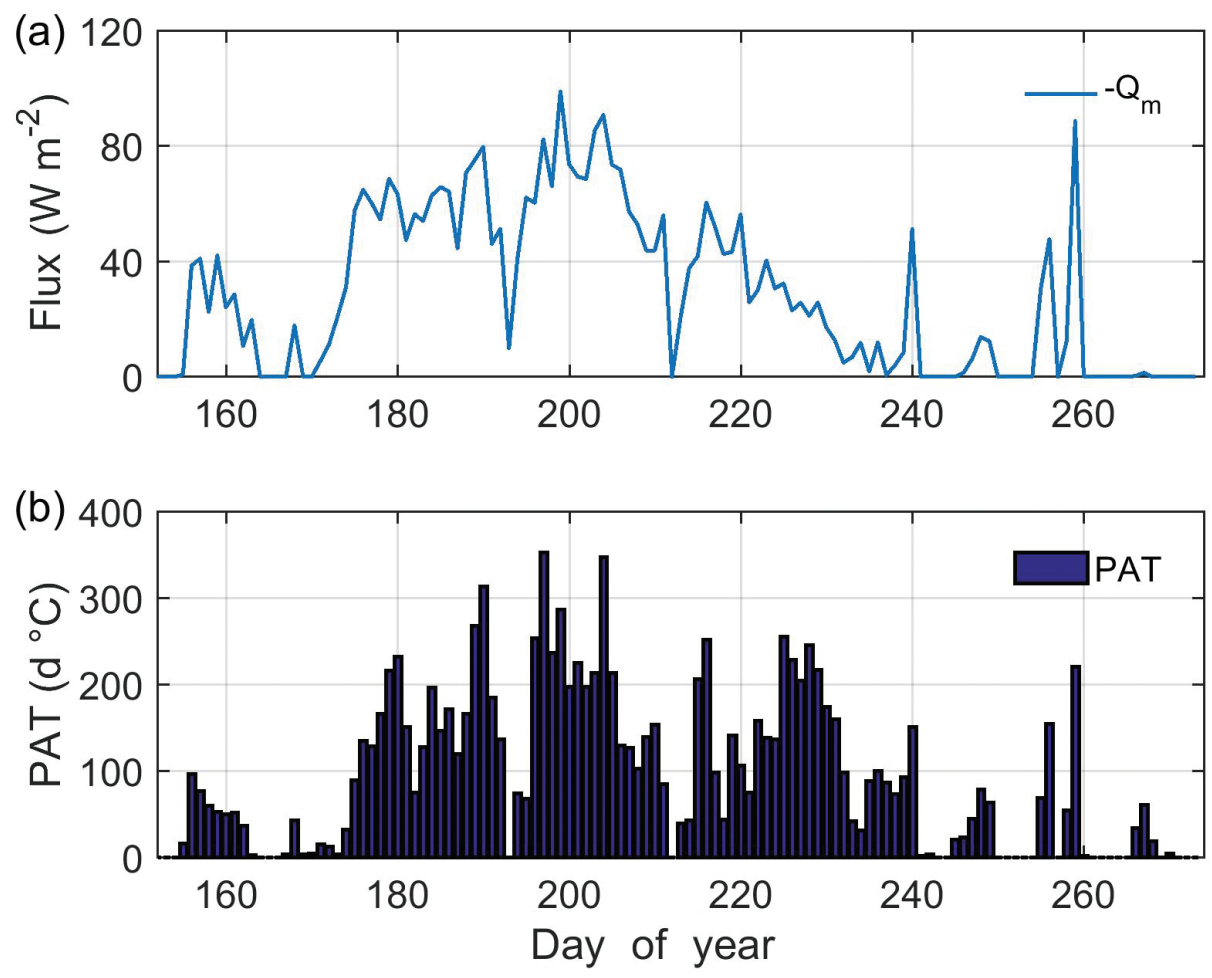

Fig. 7 Daily means of (a) melting energy $\left(Q_{m}\right)$ and (b) PAT for Austre Lovénbreen, Ny-Ålesund, during 1 June-30 September 2014. 
$Q_{\mathrm{m}}$ : high albedo coincided with low $Q_{\mathrm{m}}$ because the high albedo caused by snowfall significantly decreased $R_{\mathrm{n}}$.

In summary, $S_{\text {net }}$ was the major energy input ( $\left.39 \mathrm{~W} \mathrm{~m}^{-2}\right)$, followed by $H\left(6 \mathrm{~W} \mathrm{~m}^{-2}\right) \cdot Q_{\mathrm{m}}$ was a major energy output $\left(-29 \mathrm{~W} \mathrm{~m}^{-2}\right)$, followed by $L_{\text {net }}\left(-14 \mathrm{~W} \mathrm{~m}^{-2}\right), L E\left(-2 \mathrm{~W} \mathrm{~m}^{-2}\right)$ and $G$ (average absolute value was $<1 \mathrm{~W} \mathrm{~m}^{-2}$ ).

\section{Model evaluation}

A sonic ranger can generate information about ice melt and snow accumulation by measuring the distance between the sensor and the surface, and the values can verify the simulation of the SMB model.
The daily change in surface snow height, measured and simulated mass balance, daily precipitation, snowfall, melt (calculated) and mass balance are shown in Fig. 8. As shown in Fig. 8c, snowfall is distributed throughout the ablation period, but mainly concentrated in September in response to lower air temperature. There was a significant positive correlation between daily mass balance and albedo ( $R=0.7, n=122, p=0.01)$, which implies that daily mass balance was strongly influenced by albedo. A low albedo means more $S_{\text {net }}$ absorption by the glacier, resulting in more energy available for melting. As shown in Fig. 8, July experienced most significant mass loss, following high air temperature, high incoming solar radiation and low albedo.

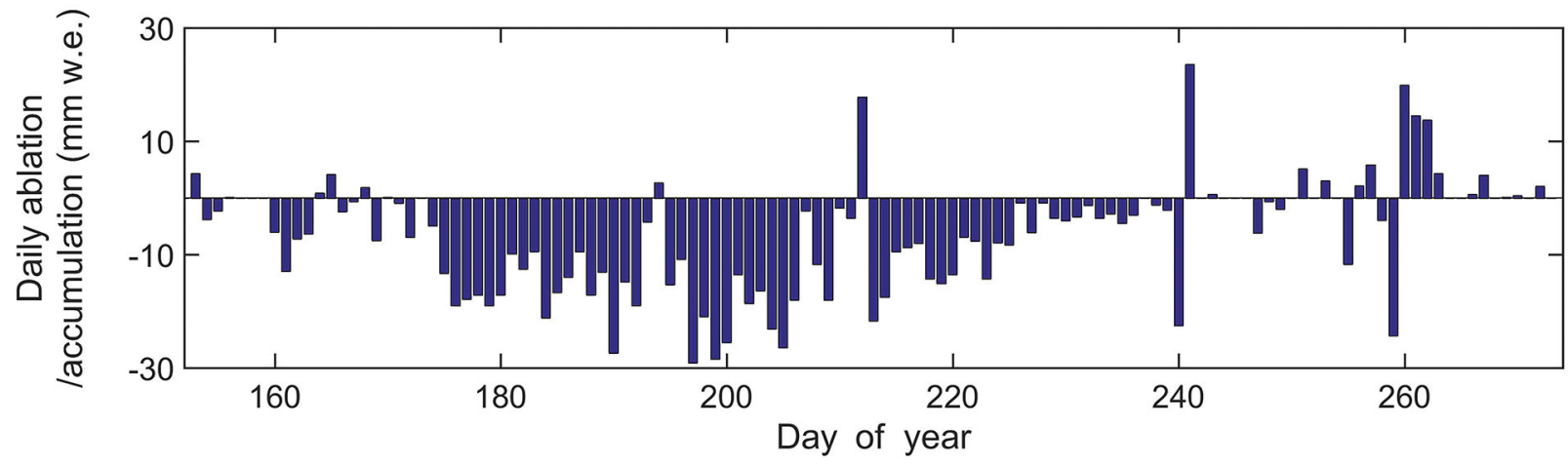

(a)
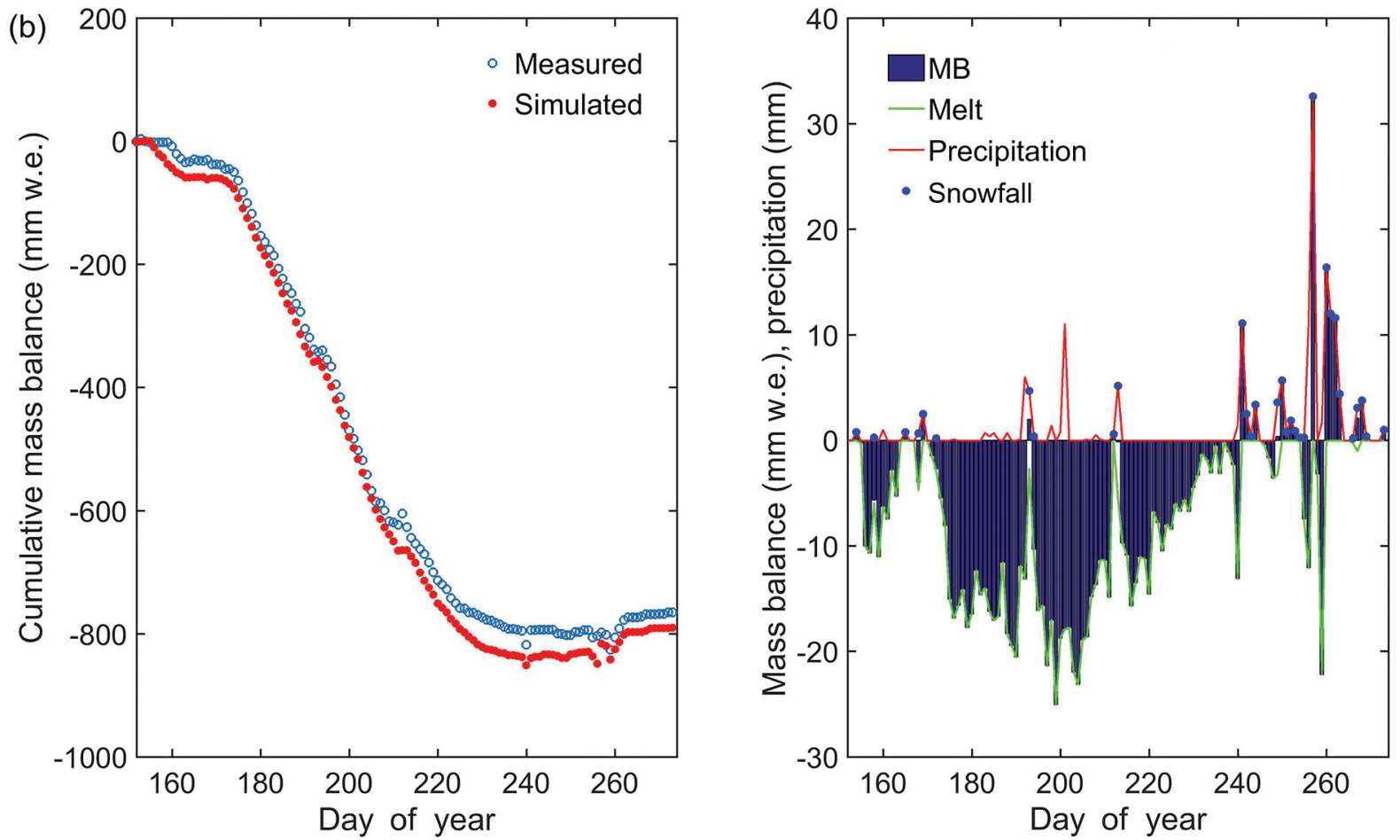

(c)

Fig. 8 (a) Daily ablation or accumulation based on the change in surface snow height from sonic ranger. (b) Comparison of measured and simulated SMB. (c) Daily precipitation, snowfall, melt (calculated) and mass balance, respectively. 
In order to assess the credibility of the SEB model, the simulated and measured daily cumulative mass balance (Fig. $8 \mathrm{~b}$ ) were compared. The minimum value of the simulated mass balance is $-850.6 \mathrm{~mm}$ w.e. on 28 August (DOY 240), which is $33.3 \mathrm{~mm}$ w.e. lower than the measured value, and the maximum absolute difference between the simulated and measured values equals $59.2 \mathrm{~mm}$ w.e., accounting for only $7 \%$ of the simulated value. Because of increasing snowfall and decreasing glacier melt after 16 September (DOY 259), the mass loss decreased, and the simulated value was $-789.5 \mathrm{~mm}$ w.e. on 30 September (DOY 273), which is $24.5 \mathrm{~mm}$ w.e. lower than the measured value. In addition, with an RMSE of $31 \mathrm{~mm}$ w.e. and an NSE of 0.99, the simulation agreed well with the measurements. Therefore, simulation of the SEB model was demonstrated to be accurate and robust.

\section{Conclusions}

In order to better understand the physical process of snow/ice-air interaction in the Arctic, meteorological observations were analysed during the ablation period 2014 on the glacier Austre Lovénbreen, Svalbard. The surface energy budget was examined on the basis of the observational data.

The length of the ablation period was approximately 105 days (4 June to 16 September). Due to a decline in albedo, high insolation and high air temperature, July experienced strongest melting. During the ablation period, $S_{\text {net }}$ was the main energy source, with a mean value of $39 \mathrm{~W} \mathrm{~m}^{-2}$, which accounted for $87 \%$ of the energy, followed by $H\left(6 \mathrm{~W} \mathrm{~m}^{-2}\right)$ at $13 \% . Q_{\mathrm{m}}$ was the primary energy output $\left(-29 \mathrm{~W} \mathrm{~m}^{-2}, 63 \%\right)$, followed by $L_{\text {net }}$ $\left(-14 \mathrm{~W} \mathrm{~m}^{-2}, 31 \%\right), L E\left(-2 \mathrm{~W} \mathrm{~m}^{-2}, 5 \%\right)$ and $G$ (the absolute value was $<1 \mathrm{~W} \mathrm{~m}^{-2}$, that is, less than $1 \%$ ).

Even though we were able to assess the full-energy budget of a site on Austre Lovénbreen during one ablation season, the scarcity of long-term available data hinders our ability to perform more detailed analysis. SEB studies with longer AWS data records are needed to better understand energy and mass exchanges between the atmosphere and glacier surfaces.

\section{Acknowledgements}

The authors thank the Chinese National Arctic Scientific Expedition (CHINARE) for their fieldwork and the National Arctic and Antarctic Data Center for providing data on the Austre Lovénbreen. They also thank the anonymous reviewers whose comments helped to improve this article.

\section{Disclosure statement}

The authors report no conflict of interest.

\section{Funding}

The study was supported financially by the National Science Foundation of China (Project approval Nos. 42122047,41941012 and 42171121 ), Ministry of Science and Technology of the People's Republic of China (Project approval Nos. 2019YFC1509100 and 2018YFC1406103) and the Basic Fund of Chinese Academy Meteorological and Sciences (Project approval Nos. $2017 Z 002$ and 2019Z005).

\section{Data availability statement}

The data sets generated for this study are available upon request from the corresponding author.

\section{References}

Aas K.S., Berntsen T.K., Boike J., Etzelmüller B., Kristjánsson J.E., Maturilli M., Schuler T.V., Stordal F. \& Westermann S. 2015. A comparison between simulated and observed surface energy balance at the Svalbard archipelago. Journal of Applied Meteorology and Climatology 54, 1102-1119, doi: 10.1175/JAMC-D-14-0080.1.

Ai S.T., Ding X., An J.C., Lin G.B., Wang Z.M. \& Yan M. 2019. Discovery of the fastest ice flow along the central flow line of Austre Lovénbreen, a poly-thermal valley glacier in Svalbard. Remote Sensing 11, article no. 1488. doi: 10.3390/ rs11121488.

Ai S.T., Wang Z.M., E D.C. \& Yan M. 2012. Surface movement research of Arctic glaciers using GPS method. Geomatics and Information Science of Wuhan University 37, 1337-1340, doi: 10.1007/s11783-011-0280-z.

Arnold N.S. \& Rees W.G. 2003. Self-similarity in glacier surface characteristics. Journal of Glaciology 49, 547-554, doi: 10.3189/172756503781830368.

Arnold N.S., Rees W.G., Hodson A.J. \& Kohler J. 2006. Topographic controls on the surface energy balance of a High Arctic valley glacier. Journal of Geophysical Research-Earth Surface 111, F02011, doi: 10.1029/2005JF000426.

Beesley J.A. 2000. Estimating the effect of clouds on the Arctic surface energy budget. Journal of Geophysical Research-Atmospheres 105, 10103-10117, doi: 10.1029/2000jd900043.

Beljaars A.C.M. \& Holtslag A.A.M. 1991. Flux parameterization over land surfaces for atmospheric models. Journal of Applied Meteorology 30, 327-341, doi: 10.1175/ 1520-0450(1991)030<0327:FPOLSF>2.0.CO;2.

Bernard E., Friedt J.M., Schiavone S., Tolle F. \& Griselin M. 2018. Assessment of periglacial response to increased runoff: an Arctic hydrosystem bears witness. Land Degradation and Development 29, 3709-3720, doi: 10.1002/ldr.3099. 
Boike J., Roth K. \& Ippisch O. 2003. Seasonal snow cover on frozen ground: energy balance calculations of a permafrost site near Ny-Ålesund, Spitsbergen. Journal of Geophysical Research-Atmospheres 108, article no. 8163, doi: 10.1029/2001jd000939.

Bougamont M., Bamber J.L. \& Greuell W. 2005. A surface mass balance model for the Greenland Ice Sheet. Journal of Geophysical Research-Earth Surface 110, F04018, doi: 10.1029/2005JF000348.

Businger J.A., Wyngaard J.C., Izumi Y. \& Bradley E.F. 1971. Flux-profile relationships in the atmospheric surface layer. Journal of the Atmospheric Sciences 28, 181-189, doi: 10.1175/1520-0469(1971)028<0181:FPRITA>2.0.CO;2.

Chechin D.G., Makhotina I.A., Lüpkes C. \& Makshtas A.P. 2019. Effect of wind speed and leads on clear-sky cooling over Arctic sea ice during polar night. Journal of the Atmospheric Sciences 76, 2481-2503, doi: 10.1175/JAS-D-18-0277.1.

Chen J.Z., Qin X., Kang S.C., Du W.T., Sun W.J. \& Liu Y.S. 2018. Effects of clouds on surface melting of Laohugou glacier No. 12, western Qilian Mountains, China. Journal of Glaciology 64, 89-99, doi: 10.1017/jog.2017.82.

Conway J.P. \& Cullen N.J. 2016. Cloud effects on surface energy and mass balance in the ablation area of Brewster Glacier, New Zealand. The Cryosphere 10, 975-1019, doi: 10.5194/tc-10-313-2016.

Cristóbal J., Prakash A., Anderson M.C., Kustas W.P., Euskirchen E.S. \& Kane D.L. 2017. Estimation of surface energy fluxes in the Arctic tundra using the remote sensing thermal-based two-source energy balance model. Hydrology and Earth System Sciences 21, 1339-1358, doi: 10.5194/ hess-21-1339-2017.

Deng H.B., Lu L.H. \& Bian L.G. 2006. Surface radiation characteristics at Ny-Ålesund over the Arctic tundra area. Chinese Journal of Polar Research 18, 254-264, doi: 10.1109/ TPSD.2006.5507455.

Ding M.H., Agrawal A., Heil P. \& Yang D.Y. 2019. Surface energy balance on the Antarctic plateau as measured with an automatic weather station during 2014. Advances in Polar Science 30, 93-105, doi: 10.13679/j.advps.2018.0050.

Ding M.H., Wang S.J. \& Sun W.J. 2018. Decadal climate change in Ny-Ålesund, Svalbard, a representative area of the Arctic. Condensed Matter 3, article no. 12, doi: 10.3390/ condmat3020012.

Ding M.H., Yang D.Y., Van den Broeke M.R., Allison I., Xiao C.D., Qin D.H. \& Huai B.J. 2020. The surface energy balance at Panda 1 Station, Princess Elizabeth Land: a typical katabatic wind region in East Antarctica. Journal of Geophysical Research-Atmospheres 125, e2019JD030378, doi: 10.1029/2019JD030378.

Dou T.F., Du Z.H., Li S.T., Zhang Y.L., Zhang Q., Hao M.J., Li C.J., Tian B., Ding M.H. \& Xiao C.D. 2019. Brief communication: An alternative method for estimating the scavenging efficiency of black carbon by meltwater over sea ice. The Cryosphere 13, 3309-3316, doi: 10.5194/tc-2019-147.

Dou T.H., Xiao C.D., Liu J.P., Han W., Du Z.H., Mahoney A.R. \& Jones J. 2019. A key factor initiating surface ablation of Arctic sea ice: earlier and increasing liquid precipitation. The Cryosphere 13, 1233-1246, doi: 10.5194/ tc-13-1233-2019.
Dürr B. \& Philipona R. 2004. Automatic cloud amount detection by surface longwave downward radiation measurements. Journal of Geophysical Research-Atmospheres 109, D05201, doi: org/10.1029/2003JD004182.

Favier V., Wagnon P., Chazarin J.P., Maisincho L. \& Coudrain A. 2004. One-year measurements of surface heat budget on the ablation zone of Antezana Glacier 15, Ecuadorian Andes. Journal of Geophysical Research-Atmospheres 109, D18105, doi: 10.1029/2003JD004359.

Franco B., Fettweis X. \& Erpicum M. 2013. Future projections of the Greenland Ice Sheet energy balance driving the surface melt. The Cryosphere 7, 1-18, doi: 10.5194/ tc-7-1-2013.

Hanna E., Huybrechts P., Steffen K., Cappelen J., Huff R., Shuman C., Irvine-Fynn T., Wise S. \& Griffiths M. 2008. Increased runoff from melt from the Greenland Ice Sheet: a response to global warming. Journal of Climate 21, 331-341, doi: 10.1175/2007JCLI1964.1.

Harstveit K. 1984. Snowmelt modelling and energy exchange between the atmosphere and a melting snow cover. Scientific Report 4. Bergen: Geophysical Institute, Meteorological Division, University of Bergen.

Hock R. 2005. Glacier melt: a review of processes and their modelling. Progress in Physical Geography 29, 362-391, doi: 10.1191/0309133305pp453ra.

Huai B.J., Van den Broeke M.R. \& Reijmer C. H. 2020. Longterm surface energy balance of the western Greenland Ice Sheet and the role of large-scale circulation variability. The Cryosphere 14, 4181-4199, doi: 10.5194/tc-2020-138.

Jiang X., Wang N.L., He J.Q., Wu X.B. \& Song G.J. 2010. A distributed surface energy and mass balance model and its application to a mountain glacier in China. Chinese Science Bulletin 55, 2079-2087, doi: 10.1007/s1 1434-010-3068-9.

IPCC (Intergovernmental Panel on Climate Change) 2019. Summary for policymakers. In H.-O. Pörtner et al. (eds.): Special report on the ocean and cryosphere in a changing climate. Accessed on the internet at https://www.ipcc.ch/ srocc/chapter/summary-for-policymakers/ on 10 November 2021 .

Karner F., Obleitner F., Krismer T., Kohler J. \& Greuell W. 2013. A decade of energy and mass balance investigations on the glacier Kongsvegen, Svalbard. Journal of Geophysical Research-Atmospheres 118, 3986-4000, doi: 10.1029/2012JD018342.

Klok E.L. \& Oerlemans J. 2002. Model study of the spatial distribution of the energy and mass balance of Morteratschgletscher, Switzerland. Journal of Glaciology 48, 505-518.

Klok E.J., Nolan M. \& Van den Broeke M.R. 2005. Analysis of meteorological data and the surface energy balance of McCall Glacier, Alaska, USA. Journal of Glaciology 51, 451-461, doi: 10.3189/172756505781829241.

Köhler A., Nuth C. Weidle C., Gibbons S.J. \& Schweitzer J. 2015. Dynamic glacier activity revealed through passive regional seismic monitoring on Spitsbergen, Svalbard. Polar Research 34, article no. 26178, doi: 10.3402/polar. v34.26178.

Kohler J., Nordli Ø., Brandt O., Isaksson E., Pohjola V., Martma T. \& Aas H.F. 2002. Svalbard temperature and 
precipitation, late 19th century to the present. Final report on ACIA-funded project. Accessed on the internet at https:// notendur.hi.is/oi/AG-326\%202006\%20readings/Holocene $\% 20$ readings/Kohler\%20et \%20al\%20Svalbard \% 20 climate.pdf on 12 October 2021.

König M., Nuth C., Kohler J., Moholdt G. \& Pettersen R. 2014. A digital glacier database for Svalbard. In J.S. Kargel et al. (eds.): Global land ice measurements from space. Pp. 229-239. Cham, Switzerland: Springer.

Kuhn M. 2011. The microclimate of valley glaciers. Journal of Glaciology 57, 1173-1174, doi: 10.3189/002214311798843313.

Kupfer H., Herber A. \& König-Langlo G. 2006. Radiation measurements and synoptic observations at Ny-Alesund, Svalbard. Bremerhaven: Alfred Wegener Institute for Polar and Marine Research.

Liston G.E. \& Elder K. 2006. A meteorological distribution system for high-resolution terrestrial modeling (MicroMet). Journal of Hydrometeorology 7, 217-234, doi: 10.1175/ JHM486.1.

Louis J.F., Tiedtke M. \& Geleyn J.F. 1982. A short history of the operational PBL-parameterization at ECMWF. Accessed on the internet at https://www.ecmwf.int/node/10845 on 12 October 2021.

Ma Y.F., Bia L.G., Xiao C.D. \& Dou T.F. 2011. Characteristics of near surface turbulent parameters along the traverse route from Zhongshan Station to Dome A, East Antarctic. Chinese Journal of Geophysics 54, 1960-1971, doi: 10.3969/j. issn.00015733.2011.08.003.

Marlin C., Tolle F., Griselin M., Bernard E., Saintenoy A., Quenet M. \& Friedt J.M. 2017. Change in geometry of a High Arctic glacier from 1948 to 2013 (Austre Lovénbreen, Svalbard). Geografiska Annaler Series A 99, 115-138, doi: 10.1080/04353676.2017.1285203.

Maturilli M., Herber A. \& König-Langlo G. 2012. Climatology and time series of surface meteorology in Ny-Ålesund, Svalbard. Earth System Science Data 5, 155-163, doi: 10.5194/essdd-5-1057-2012.

Midgley N.G., Cook S.J., Graham D.J. \& Tonkin T.N. 2013. Origin, evolution and dynamic context of a neoglacial lateral-frontal moraine at Austre Lovénbreen, Svalbard. Geomorphology 198, 96-106, doi: 10.1016/j.geomorph.2013.05.017.

Mölg T. \& Hardy D.R. 2004. Ablation and associated energy balance of a horizontal glacier surface on Kilimanjaro. Journal of Geophysical Research-Atmospheres 109, D16104. doi: 10.1029/2003jd004338.

Nakabayashi H., Kodama Y., Takeuchi Y., Ozeki T. \& Ishikawa N. 1996. Characteristics of heat balance during the snowmelt season in Ny-Ålesund, Spitsbergen Island. Memoirs of National Institute of Polar Research, Spec. Issue, 51, 255-266.

Nakamura N. \& Oort A.H. 1988. Atmospheric heat budgets of the polar regions. Journal of Geophysical Research-Atmospheres 93, 9510-9524, doi: 10.1029/JD093iD08p09510.

Nash J.E. \& Sutcliffe J.V. 1970. River flow forecasting through conceptual models part I-a discussion of principles. Journal of Hydrology 10, 282-290, doi: 10.1016/0022-1694(70)90255-6.

Nordli Ø. \& Kohler J. 2004. The early 20th century warming. Daily observations at Gronfjorden and Longyearbyen on Spitsbergen. 2nd edn. Klima 12/03. Oslo: Norwegian Meteorological Institute.
Nordli Ø., Przybylak R., Ogilvie A.E. \& Isaksen K. 2014. Longterm temperature trends and variability on Spitsbergen: the extended Svalbard Airport temperature series, 1898-2012. Polar Research 33, article no. 21349, doi: 10.3402/polar. v33.21349.

Nuth C., Moholdt G., Kohler J., Hagen J.O. \& Kääb A. 2010. Svalbard glacier elevation changes and contribution to sea level rise. Journal of Geophysical Research-Earth Surface 115, F01008, doi: 10.1029/2008JF001223.

Oerlemans J., Giesen R.H. \& Van den Broek M.R. 2009. Retreating alpine glaciers: increased melt rates due to accumulation of dust (Vadret da Morteratsch, Switzerland). Journal of Glaciology 55, 729-736, doi: 10.3189/0022 14309789470969.

Oerlemans J., Jania J. \& Kolondra L. 2011. Application of a minimal glacier model to Hansbreen, Svalbard. The Cryosphere 5, 1-11, doi: 10.5194/tc-5-1-2011.

Oerlemans J. \& Klok E.J. 2002. Energy balance of a glacier surface: analysis of automatic weather station data from the Morteratschgletscher, Switzerland. Arctic, Antarctic, and Alpine Research 34, 477-485, doi: 10.1080/15230430.2002. 12003519.

Ohmura A. 2012. Present status and variations in the Arctic energy balance. Polar Science 6, 5-13, doi: 10.1016/j. polar.2012.03.003.

Oke T.R. 1987. Boundary layer climates. 2nd edn. New York: Routledge.

Østby T.I., Schuler T.V., Hagen J.O., Hock R., Kohler J. \& Reijmer C.H. 2017. Diagnosing the decline in climatic mass balance of glaciers in Svalbard over 1957-2014. The Cryosphere 11, 191-215, doi: 10.5194/tc-11-191-2017.

Pramanik A., Kohler J., Schuler T.V., Van Pelt W. \& Cohen L. 2019. Comparison of snow accumulation events on two High Arctic glaciers to model-derived and observed precipitation. Polar Research 38, article no. 3364, doi: 10.33265/ polar.v38.3364.

Radić V. \& Hock R. 2014. Glaciers in the Earth's hydrological cycle: assessments of glacier mass and runoff changes on global and regional scales. Surveys in Geophysics 35, 813-837, doi: 10.1007/s10712-013-9262-y.

Raschke E. \& Ohmura A. 2005. Radiation budget of the climate system (Chapter 4). Observed Global Climate. Group V: Geophysics, Landolt-Börnstein Numerical and Functional Relationships in Science and Technology, New Series, Vol. 6, 4-1.

Saintenoy A., Friedt J. M., Tolle F., Bernard E., Laffly D., Marlin C. \& Griselin M. 2011. High density coverage investigation of the Austre Lovénbreen (Svalbard) using ground penetrating radar. In: 2011 6th International Workshop on Advanced Ground Penetrating Radar (IWAGPR). Doi: 10.1109/IWAGPR.2011.5963894. New York: Institute of Electrical and Electronics Engineers.

Sauter T. \& Obleitner F. 2015. Assessing the uncertainty of glacier mass-balance simulations in the European Arctic based on variance decomposition. Geoscientific Model Development 8, 3911-3928, doi: 10.5194/gmd-8-3911-2015.

Screen J.A. \& Simmonds I. 2010. The central role of diminishing sea ice in recent Arctic temperature amplification. Nature 464, 1334-1337, doi: 10.1038/nature09051. 
Sedlar J., Tjernström M., Mauritsen T., Shupe M.D., Brooks I.M., Persson P.O.G., Birch C.E., Leck C., Sirevaag A. \& Nicolaus M. 2011. A transitioning Arctic surface energy budget: the impacts of solar zenith angle, surface albedo and cloud radiative forcing. Climate Dynamics 37, 1643-1660, doi: 10.1007/s00382-010-0937-5.

Serreze M.C., Barrett A.P., Slater A.G., Steele M., Zhang J. \& Trenberth K.E. 2007. The large-scale energy budget of the Arctic. Journal of Geophysical Research-Atmospheres 112, D11122, doi: 10.1029/2006JD00823.

Serreze M.C. \& Barry R.G. 2011 . Processes and impacts of Arctic amplification: a research synthesis. Global and Planetary Change 77, 85-96, doi: 10.1016/j.gloplacha.2011.03.004.

Sheng P.X. 2013. Atmospheric physics. Beijing: Peking University Press.

Sun W.J., Qin X., Wang Y.T., Chen J.Z., Du W.T., Zhang T. \& Huai B.J. 2018. The response of surface mass and energy balance of a continental glacier to climate variability, western Qilian Mountains, China. Climate Dynamics 50, 35573570, doi: 10.1007/s00382-017-3823-6.

Sun W.J., Yan M., Ai S.T., Zhu G.C., Wang Z.M., Liu L.B., $\mathrm{Xu}$ Y.T. \& Ren J.W. 2016. Ice temperature characteristics of the Austre Lovenbreen glacier in Ny-Ålesund, Arctic region. Geomatics and Information Science of Wuhan University 36, 676-678, doi: 10.13203/j.whugis20150302.

van den Broeke M., Reijmer C., van As D. \& Boot W. 2006. Daily cycle of the surface energy balance in Antarctica and the influence of clouds. International Journal of Climatology 26, 1587-1605, doi: 10.1002/joc.1323.

van den Broeke M., Reijmer C. \& van de Wal R. 2004a. A study of the surface mass balance in Dronning Maud Land, Antarctica, using automatic weather stations. Journal of Glaciology 50, 565-582, doi: 10.3189/172756504781829756.

van den Broeke M., Reijmer C. \& van de Wal R. 2004b. Surface radiation balance in Antarctica as measured with automatic weather stations. Journal of Geophysical ResearchAtmospheres 109, 715-728, doi: 10.1029/2003jd004394.

van den Broeke M., Smeets P., Ettema J. \& Munneke P.K. 2008. Surface radiation balance in the ablation zone of the West Greenland Ice Sheet. Journal of Geophysical Research-Atmospheres 113, article no. D13105, doi: 10.1029/2007JD009283.

van den Broeke M., Smeets P., Ettema J., van der Veen C., van de Wal R. \& Oerlemans J. 2008. Partitioning of melt energy and meltwater fluxes in the ablation zone of the West Greenland Ice Sheet. The Cryosphere 2, 179-189, doi: 10.5194/tcd-2-711-2008.

van den Broeke M.R, Smeets C.J.P.P. \& van de Wal R.S.W. 2011. The seasonal cycle and interannual variability of surface energy balance and melt in the ablation zone of the West Greenland Ice Sheet. The Cryosphere 5, 377-390, doi: 10.5194/tc-5-377-2011.

van den Broeke M., van As D., Reijmer C. \& van de Wal R. 2004. Assessing and improving the quality of unattended radiation observations in Antarctica. Journal of Atmospheric and Oceanic Technology 21, 1417-1431, doi: 10.1175/1520-0426(2004)0212.0.CO;2.

van den Broeke M., van As D., Reijmer C. \& van de Wal R. 2005. Sensible heat exchange at the Antarctic snow surface: a study with automatic weather stations. International Journal of Climatology 25, 1081-110, doi: 10.1002/ joc. 1152 .

van Pelt W. \& Kohler J. 2015. Modelling the long-term mass balance and firn evolution of glaciers around Kongsfjorden, Svalbard. Journal of Glaciology 61, 731-744. doi: 10.3189/2015JoG14J223.

van Pelt W., Pohjola V., Pettersson R., Marchenko S., Kohler J., Luks B., Hagen J.O., Schuler T.V., Dunse T., Noel B. \& Reijmer C. 2019. A long-term dataset of climatic mass balance, snow conditions, and runoff in Svalbard (1957-2018). The Cryosphere 13, 2259-2280, doi: 10.5194/tc-2019-53.

Wagnon P., Sicart J.E., Berthier E. \& Chazarin J.P. 2003. Wintertime high-altitude surface energy balance of a Bolivian glacier, Illimani, $6340 \mathrm{~m}$ above sea level. Journal of Geophysical Research-Atmospheres 108, article no. 4177, doi: 10.1029/2002jd002088.

Wang Z.M., Lin G.B. \& Ai S.T. 2019. How long will an Arctic mountain glacier survive? A case study of Austre Lovénbreen, Svalbard. Polar Research 38, article no. 3519 , doi: 10.33265/polar.v38.3519.

Wei T., Ding M.H., Wu B.Y., Lu C.G. \& Wang S.J. 2016. Variations in temperature-related extreme events (1975-2014) in Ny-Ålesund, Svalbard. Atmospheric Science Letters 17, 102-108, doi: 10.1002/asl.632.

Westermann S., Lüers J., Langer M., Piel K. \& Boike J. 2009. The annual surface energy budget of a High-Arctic permafrost site on Svalbard, Norway. Cryosphere Discussions 2, 245-263, doi: 10.5194/tcd-3-631-2009.

Yamanouchi T. 2018. Arctic warming by cloud radiation enhanced by moist air intrusion observed at Ny-Ålesund, Svalbard. Polar Science 21, 110-116, doi: 10.1016/j. polar.2018.10.009.

Yang W., Guo X.F., Yao T.D., Yang K., Zhao L., Li S.H. \& Zhu M.L. 2011 . Summertime surface energy budget and ablation modeling in the ablation zone of a maritime Tibetan glacier. Journal of Geophysical Research-Atmospheres 116, D14116, doi: 10.1029/2010JD015183.

Yang W., Guo X.F., Yao T.D., Zhu M.L. \& Wang Y.J. 2016. Recent accelerating mass loss of southeast Tibetan glaciers and the relationship with changes in macroscale atmospheric circulations. Climate Dynamics 47, 805-815, doi: 10.1007/s00382-015-2872-y.

Zhang G.S., Kang S.C., Fujita K., Huintjes E., Xu J.Q., Yamazaki T., Haginoya S., Wei Y., Scherer D., Schneider C. \& Yao T.D. 2013. Energy and mass balance of Zhadang glacier surface, central Tibetan Plateau. Journal of Glaciology 59, 137-148, doi: 10.3189/2013JoG12J152.

Zhang R.D., Wang H.L., Fu Q., Rasch P.J. \& Wang X.J. 2019. Unraveling driving forces explaining significant reduction in satellite-inferred Arctic surface albedo since the 1980s. Proceedings of the National Academy of Sciences of the United States of America 116, 23947-23953, doi: 10.1073/pnas.1915258116.

Zhang Y.L., Kang S.C., Cong Z.Y., Schmale J., Sprenger M., Li C.L., Yang W., Gao T.G., Sillanpaa M., Li X.F., Liu Y.J., Chen P.F. \& Zhang X.L. 2017. Light-absorbing impurities enhance glacier albedo reduction in the southeastern Tibetan Plateau. Journal of Geophysical Research-Atmospheres 122, 6915-6933, doi: 10.1002/2016JD026397. 